Xavier University

\title{
Exhibit
}

Fall 2011

\section{Choreographing Exile: Lothar Warneke's and Omar Saavedra Santis's Blonder Tango}

Jamie Trnka

Follow this and additional works at: https://www.exhibit.xavier.edu/modern_languages_faculty

\section{Recommended Citation}

Trnka, Jamie, "Choreographing Exile: Lothar Warneke's and Omar Saavedra Santis's Blonder Tango" (2011). Faculty Scholarship. 11.

https://www.exhibit.xavier.edu/modern_languages_faculty/11

This Article is brought to you for free and open access by the Modern Languages at Exhibit. It has been accepted for inclusion in Faculty Scholarship by an authorized administrator of Exhibit. For more information, please contact exhibit@xavier.edu. 


\section{WILEY}

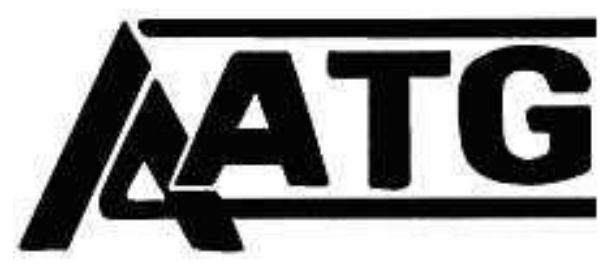

Choreographing Exile: Lothar Warneke's and Omar Saavedra Santis's "Blonder Tango" Author(s): Jamie H. Trnka

Source: The German Quarterly, Vol. 84, No. 3 (Summer 2011), pp. 309-327

Published by: Wiley on behalf of the American Association of Teachers of German

Stable URL: https://www.jstor.org/stable/41237102

Accessed: 22-11-2019 21:07 UTC

JSTOR is a not-for-profit service that helps scholars, researchers, and students discover, use, and build upon a wide range of content in a trusted digital archive. We use information technology and tools to increase productivity and facilitate new forms of scholarship. For more information about JSTOR, please contact support@jstor.org.

Your use of the JSTOR archive indicates your acceptance of the Terms \& Conditions of Use, available at https://about.jstor.org/terms

Wiley, American Association of Teachers of German are collaborating with JSTOR to digitize, preserve and extend access to The German Quarterly 
JAMIE H. TRNKA

The University of Scranton

\title{
Choreographing Exile: Lothar Warneke's and Omar Saavedra Santis's Blonder Tango
}

\author{
"Ich habe selten eine so spontane, so politische und so \\ emotionale Reaktion unserer Bevölkerung auf ein Ereignis in \\ einem anderen Erdteil erlebt, wie an diesen Septembertagen des \\ Jahres 1973 als uns die Nachrichten und Bilder von dem \\ Militärputsch in Chile und der Ermordung des Präsidenten Salva- \\ dor Allende erreichten. Die gnadenlose Härte der \\ Auseinandersetzung zwischen der imperialistischen Reaktion \\ und dem gesellschaftlichen Fortschritt trat uns bildhaft vor \\ Augen, war plötzlich in unseren Zimmern, in unserem Alltag \\ anwesend." (Warneke, "Treatment" I)
}

With these words, Lothar Warneke introduced his film treatment of a novel by exiled Chilean author Omar Saavedra Santis, who had lived in the German Democratic Republic (GDR) since 1974. ${ }^{1}$ Warneke's emphasis on the power of visual information and narratives to effect a sense of Chilean life transported to the GDR over a decade prior to his film's completion reflects more than an eager director's pitch to the studio. The 1970 Popular Front victory in Chile had resulted in a number of international exchange agreements and friendship treaties between the GDR and Salvador Allende's democratically elected socialist government. To already strong cultural, political, and economic commitments to Latin American socialism was added the affective celebration of socialist victory in newsreels, short educational films, and print media, not to mention the intensely emotional hopes for a "third way" among committed socialists who were nonetheless critical of the limited freedoms they enjoyed in the Soviet bloc. ${ }^{2}$ East German interest in Chile redoubled with news of the coup. Large numbers of Chileans associated with the socialist and communist parties, including such prominent figures as Chilean Communist Party leaders Luis Corvalán and Gladys Marín, were granted exile in the GDR. In all, an estimated 2,000 Chileans came to the GDR, many of them artists and intellectuals (Polster 24). Over the next several years, community festivals, television, and film contributed to the East Germans' visual archive of the 
Pinochet coup, and were supplemented by radio dramas, Chilean popular song, and literature.

While earlier theatrical and prose writings by Chileans in the GDR focused largely on the political and social situation in Chile, Saavedra Santis's 1983 novel ¿Y qué hago yo en este país donde todos los gatos son rubios? (literally: And What Am I Doing in this Country Where All the Cats Are Blonde?), published in German translation as Blonder Tango, was the first to describe the lived experience of Chilean exile in the GDR. To date, the novel has not appeared in Spanish. The film version was awarded the GDR Critics' Prize, making it the only successful DEFA feature film to deal with the topic of exiles or foreigners in East Germany, and offering a striking counterpoint to more explicitly aestheticized figurations of the tango in East German film, such as Helke Misselwitz's Tango Traum (1985). And yet, curiously, in the work at issue here, the tango emerges only at the moment of translation: neither the title nor the text of the novel nor, later, the film contains significant references to tango.

Tango is an enduring cliché that serves in Blonder Tango as a generic referent to South America's Southern Cone. There is no single tango: variants abound across countries, continents, and milieus. Tango's ascent to titular prominence raises a series of questions, including: How should one account for cliché as a function of translation (or vice versa)? Does cliché enable translation, reinforce cultural essentialisms, or both? Might cliché encapsulate more complex historical movements of people and traditions which precede any translation project? Is tango's mere juxtaposition to a cliché of "Germanness" ironically destabilizing? Finally, how can we account for the multiply translative effects of language and transmediality presented by the film?

Translative effects encompass what have variously been described as problems of equivalence, untranslatability, semiotic transference, and the visibility or even subjectivity of the translator. They manifest as slippages or indeterminate images situated in relation to multiple cultural contexts, including history and memory. In the process of translating or acculturating a source text for or to a new audience, the translator seeks to navigate a sea of references which separately may activate different cultural contexts but combine in translation to exceed the sum of discrete references in either source or target culture. In Blonder Tango, (East) German and Chilean references to Beethoven, fascism, the Spanish Civil War, and exile resonate in ways fundamentally different to un-translated texts, as I shall demonstrate.

Sandra Bermann and Michael Wood use the more encompassing term "translationality" to describe issues of broad ethical and political import at play in translation as a reflexive engagement with cultural, spatial, ontologi$\mathrm{cal}$, and historical alterities. They advocate attention to the act and necessity of translation and to the complex cultural negotiations the process entails; in a world of literal and figurative border-crossings, they argue, such attention offers educational and even global civic potentials (Bermann and Wood 7). 
Translationality underwrites and motivates my more modest inquiry into the effects of specific instances of translation in Blonder Tango the novel, the screen play, and the film, and among the creative agents at work in each. In the film version, translative effects combine with the transmedial, itself a complex rubric that I describe in more detail below.

The composite production of translative effects in the film Blonder Tango underscores the challenge and promise of translation as an expression of solidarity and the consolidation of plural subjects and speaking positions. I seek to highlight the sometimes uneasy relation of Warneke and Saavedra Santis in a translative project exclusive of any self-evident delineations among source and target language and culture, a project whose Spanish language manuscript was never published, in which a German language translation assumes the role of original, and for which the conceit of a reading public with a shared cultural context is scuttled by the fact of exile and the attendant difficulties (often impossibilities) of publication and distribution in Chile.

The uneasy relation of source and target text is compounded by antifascism's multiple narrators of creative and political solidarity. Edward Said's notion of counterpoint denotes reading/viewing "retrospectively and heterophonically" across differently located narrators of differently or even differentially valorized narratives (161). In analogy to Said's contrapuntal reading, a translative reading might offer a more expansive structure for the spatialization of music in dance-here choreographed as the tango-and the constantly shifting loci of enunciation not only of individual subjects, but also of the shifting and improvisational interrelation of partnered subjects. (One distinguishing feature of the tango is that it is widely considered to have been the first partner dance to include improvisation). Where counterpoint privileges the temporal field, a translative reading of Saavedra Santis's Chilean exile novel draws at least as much attention to territorial disjunctures as to the historical reverberations of empire. Warneke's screen directions, too, elicit specifically translative performances and editing; in production and press materials accompanying the distribution of Blonder Tango, he repeatedly calls upon translative metaphors to describe the project in terms of cultural geography.

In both iterations of Blonder Tango, translative reading opens meaningful relationships among territories, conflicts, and protagonists in tandem with a contrapuntal, historical analysis of East German and Chilean antifascisms. Competing assessments of the film as a project and an artifact are symptomatic of Blonder Tango's overlapping translative frames: historical, cultural, and political relationships at play in the film and its production refract one another, generating new German and Chilean cultural referents not present in a single original or source text in the process of collaboration. Instead, Saavedra Santis and Warneke generate comparisons among historically specific experiences of fascism, violence, and resistance, and engage concepts of solidarity 
and authenticity in their fullness-incomplete, improvised, and usually accompanied by painful missteps.

Reading Blonder Tango as reciprocally embedded in Chilean and East German discourses on fascism, antifascist solidarity, and exile contributes to ongoing debates about the geographical and conceptual boundaries of German Studies. The questions of translation and comparison that guide my analysis underscore the need for a thoughtful recalibration of interdisciplinarity within German Studies. It is not sufficient to pursue global or transnational connections in literature, history, and politics in various multidisciplinary configurations, which is to say: by means of additive rather than transformative methods. Instead, disciplinary pursuits must themselves become translative and contrapuntal if they are to query how and why disciplines organized around variously defined cultural areas have, or have not, historically constituted intercultural relationships in the first place.

Blonder Tango's point of narrative departure is a historically embedded double lie. The Chilean Rogelio is first interned and then exiled after Pinochet's coup. He takes refuge in the GDR, where he works in a theater as a lighting technician. To give his family and neighbors hope, Rogelio fabricates elaborate stories about his success and happiness, even posing for wedding photos with a reluctant friend in the role of bride and recounting in minute detail the birth of a son. Meanwhile, his mother's friends maintain their own fictions in order to avoid telling Rogelio that his mother has died in his absence. On the fifth anniversary of his exile, against a North Sea landscape that recalls his native Valparaiso, Rogelio is saved from freezing by the German antifascist Stephan Hiller, a Spanish Civil War veteran who spent World War II in Mexican exile. Warneke characterizes their ensuing relationship in his initial film treatment:

Wie kein anderer weiß er [Hiller] um die Probleme, die sich in der Seele dieses Rogelio abspielen müssen. In den Gesprächen, die die beiden miteinander führen, finden die Lebensläufe zu einer erstaunlichen Parallelität. Indem Hiller den chilenischen Emigranten auf die Internationalität des politischen Kampfes gegen die Reaktion aufmerksam macht, macht er ihn im gewissen Sinne heimisch in diesem Lande. Eine sinnliche Form ist gefunden für die Dialektik von proletarischem Internationalismus und nationaler Besonderheit. ("Treatment" II)

And this despite the fact that neither Hiller (addressed by Rogelio as Don Stefan) nor Rogelio are sympathetic internationalist heroes-the old antifascist has in effect given up the struggle and retreated internally from the GDR; Rogelio is not only a liar but a self-centered macho who has come to doubt the efficacy of his earlier political actions.

Warneke's screen play holds remarkably close to Saavedra Santis's novel. Most of the film's dialogue is taken directly from it. Warneke takes advantage 
of film's own repertoire of narrative techniques to convey the novel's multiple narrative frames. (Most prominent among them are Rogelio's flashbacks to his experiences in Chile, interior monologues, his present-day relationships to friends and colleagues at the theater and with other exiled Chileans in East and West Germany, his interactions with Hiller, and events described and imagined in correspondence with his family members.) Film effects include inserts of hand-written letters with prominent dates and place names, alternating Spanish and German voice-overs, and changes in lighting and soft-focus. GDR film critics observed that, with the resulting narrative complexity, fantasy, emotion, and international referents at play in the film version, "[d]er 'Blonde Tango' bringt uns einen neuen Lothar Warneke" (Schwarz). The novelty noted by critics and attributed to Warneke as a director tells only part of the story. It may be commonplace to say that no single individual is the author of a film text, a fact emphasized by the DEFA system of named production groups. Still, Blonder Tango's accumulation of authors and translative effects amounts to a remarkable multiplication of degree, even when compared to the many other Literaturverfilmungen DEFA produced. The resulting effect-"a new Warneke" - marks an expanded field of authorship, language, place, and time for the articulation of solidarity's personal and political allegiances, as well as its contradictions.

\section{Which Antifascism?}

Over a decade after the coup in Chile, when much of the attention of solidarity groups had passed to Nicaragua, Blonder Tango occasioned not a few local solidarity initiatives. Well-publicized musical performances and Chilean food and crafts bazaars were organized by cultural and solidarity groups to coincide with local premieres of the film. ${ }^{3}$ Coordinated by Chilean exiles and East German members of solidarity groups, such events provided a social context for audiences. As manifest dis- and re-locations of Chilean socialists and their national popular forms, the folkloric contexts of Blonder Tango premiers in major cities simultaneously celebrated socialist internationalism and drew attention to the erosion of discrete national constituencies in the world socialist project. The film's reception thus generated its own local narratives of national and international political projects. Its protagonists unmoored from their respective national bases, one imagines that it was increasingly difficult for filmgoers to say where East German antifascism stopped and Chilean antifascism began, let alone how each related to the historic formations of Spanish and German antifascisms.

In one of the few scholarly appraisals of the film, Barton Byg observes that East German antifascist and director Konrad Wolf's biography is effectively insinuated into the film version for a German audience via allusions to Wolf's 
1968 semi-autobiographical film, Ich war 19 (55-71). Wolf's film, a classic of DEFA cinema, narrates the ambivalent return of a young German émigré from the Soviet Union as part of a Soviet Aufklärungseinheit. In particular, Byg cites a series of scenes in Blonder Tango in which Rogelio, having visited the Chilean consulate in West Berlin, violently confronts three West German youths wearing the Iron Cross and Nazi insignia, ignorant racists with no knowledge of German history. Together with Rogelio, who initiates a fight by trying to remove the Iron Cross, they are assigned a minimal fine for disturbing the peace and released from police custody, though not before Rogelio and the police officer converse about history and politics in the two German states. Like the figure of the complacent architect in Ich war 19, the West German police officer disinterestedly enjoys the exchange, remarking: "Es macht mir Spaß, mich mit intelligenten Menschen zu unterhalten." Rogelio later describes his own reaction to the West German youths as a poorly made declaration of love to the GDR - "am falschen Ort und zur falschen Zeit." The similarity of these sequences in Wolf and Warneke, each of which features an antifascist protagonist confronted with a German civil servant identified with or indifferent to a legacy of German fascism, suggests the resumption of a much older line in DEFA film, in which antifascist internationalism enjoyed pride of place.

However, author Saavedra Santis, dramaturge Erika Richter, and cameraman Thomas Plenert all question the thematic and analytic purchase of antifascism in Warneke's Blonder Tango, offering responses completely at odds with one another as well as with a reading of the film that pivots on German antifascism. "I wrote a Chilean book," said Saavedra Santis, "They made a German movie" (personal interview). Prior to his death in 2005, Warneke had taken quite the opposite tack, describing a deep collaboration exemplary of an intercultural hermeneutics. He insisted on the dual nationality of the film, its transformative impact on his work and worldview. In press packets and interviews, he consistently described a collaborative writing process, even stating that Saavedra Santis edited the screenplay (Voss 8-10; Warneke, Die Schönheit 159-69). Saavedra Santis, on the other hand, acknowledges no such role and does not consider the process to have been collaborative; he claims that his only active intervention was to insist on casting Alejandro Quintana Contreras, an exiled actor and director then working at the Berliner Ensemble, as Rogelio. Saavedra Santis remains convinced that the formerly exiled Spanienkämpfer were unacknowledged and unappreciated in the GDR, and that this contributed to a flat, humorless rendering of the plot-line around Hiller and Rogelio's unlikely friendship. Richter reacted to the suggestion that DEFA's own antifascist history was inscribed into Blonder Tango with something like embarrassment, explaining that scenes from the novel in which Saavedra Santis staged his confrontation between East and West, antifascism and fascism were too overstated, too closely approximated a party-line on antifascist 
solidarity. Her assessment resonates with DEFA Zulassungsprotokollen, in which various people associated with the project describe the scenes in question as too didactic. ${ }^{4}$ Such divergent responses to a focus on antifascist traditions internal to DEFA or even to East Germany as a cultural field suggest that a generic antifascism cannot by itself offer full entry into the film. Instead, they require a broader approach attentive to translated cultural histories in Germany and Chile to explore what competing assessments of the film as a project and as an artifact tell us about the kinds of cultural labor that antifascism is doing for different constituencies in a Chilean-German relationship.

Regardless of their contradictory self-positionings relative to earlier postwar German narratives of antifascism and exile, Saavedra Santis and Warneke were part of a broader trend toward the representation of convergent antifascisms under the sign of the Spanish Civil War in East and West Germany. Their collaborative work on Blonder Tango exemplifies the significance of Spanish antifascism for Latin American and German authors since the 1930s and the resurgent interest therein in German language literature of the 1970s, most notably in works by such prominent authors as Peter Weiss (Die Ästhetik des Widerstands [1975-1981]) and Hans Magnus Enzensberger (Der kurze Sommer der Anarchie. Buenaventura Durrutis Leben und Tod [1972]). Further, it is clear that the DEFA Hauptverwaltung was interested in the relation of historical fascisms: strategic planning documents during the period from 1979-87 emphasize both the possibility of developing films about German antifascists in Mexican exile and the importance of exploring opportunities for Latin American co-productions ("Ergebnisanalyse" 7-8). A 1985 "Direktionsvorlage" recommending the project saw in Blonder Tango precisely such an opportunity:

In "Blonder Tango" verbindet sich die realistische Darstellung bestimmter Seiten unserer DDR-Alltags organisch mit der Weltsituation bzw. einem brennenden Funk derselben, nähmlich Chile, und darüber hinaus das Gegenwärtige (des Exils chilenischer Antifaschisten in der DDR) mit dem Vergangenen (des Exils deutscher Antifaschisten in Mexiko). Diese außergewöhnliche Geschichte bietet die seltene Chance, über uns zu sprechen, indem wir über unsere Freunde erzählen und umgekehrt, über die Freuden und Leiden des Exils und über die Solidarität, die in den glücklichsten Fällen ein gegenseitiges Geben und Nehmen bedeutet.

That the two authors' distinct efforts to cultivate solidarity are at odds with one another is evident in their conflicting assessments of the filmmaking process and its outcome. Less evident is what kind of solidarity remains. Translation as an analytic approach has the potential to contribute uniquely to a critical appraisal of solidarity without lapsing into a cynical dismissal of "state solidarity" or an uncritical celebration of internationalism inattentive to the asymmetries of power within the international arena. As a relation that 
is always reciprocal even when it is not symmetrical, translation can temper multiple perspectives and foster productive negotiations of difference. I am not primarily interested in whether Warneke's film constitutes a "successful" translation or, by extension, entails a "successful" or efficacious expression of solidarity; rather, I am interested in the subtle differences and contradictions in modes of thinking about solidarities of cultures, languages, and historical constellations that are articulated in and around the collective project, and in the potential consequences thereof for thinking about solidarity as a form of subjectivity.

\section{Intermediality, Translation, History}

Three aspects of the film are particularly rich points of entry into the processes underlying the treatment of antifascist solidarities. All of them are underwritten by diverse practices of comparison: intermediality, translation, and rewritings of cultural and literary histories.

First, let me venture to claim that Chilean exile literature in the 1970s and 1980s, regardless of an author's country of residence, was characterized by intermediality. Warneke's observation that Blonder Tango was already a very cinematic novel will come as little surprise to Latin Americanists (Warneke, Die Schönheit 158). Hermann Herlinghaus identifies a post-Boom sensibility to the materiality of communicative media in the literature of the Southern Cone in particular, as it seeks to represent "entterritorialisierte Realitäten" (Intermedialität 11). If this is correct, then intermedial exile writings in East Germany and the Chilean-East German collaborative projects they sparked cut across more conventional attempts to emplot discrete national subjects of international antifascist solidarity in DEFA documentary and educational cinema. ${ }^{5}$ They tendentiously erode the socialist modern predicated on localized subjects of productive labor.

In the novel Blonder Tango, focal media include theater, opera, personal and official correspondence, political speeches, and song lyrics. That an intermedial work of literature is itself translated in the process of producing a film contributes to a layering of the inter- and the trans-medial. With Herlinghaus, I use the term transmedial to describe "Prozeduren und Wechselwirkungen, die mit einem medialen Gestalt- und Funktionswechsel verbunden sind," while intermedial denotes further reaching shifts in the discursive field(s) under consideration. He offers the following distinction:

Intermedialität, hingegen, soll als Suchbegriff für jene Verfahren und Diskurspraktiken dienen, die-ohne die vermeintlichen Grenzen eines Mediums zu überschreiten - die ästhetisch und funktional relevante Assimilation von Strukturcodes und narrativen Mustern beziehungsweise medialer Praktiken bezeichnen. (Intermedialität 19) 
Attention to intermediality could ultimately foreground other modes of transfer, transformation, and artifice at work in mobilizing and resemanticizing forms of aesthetic solidarity.

A complex constellation of historical events and institutions contributed to Chilean exiles' heightened attention to media, generic boundaries, and their creative manipulation in prose fiction. Chile in the early twentieth century was the site of a number of publishing ventures begun by Chilean nationals and exiled Spanish antifascists. As literacy rates increased, so, too, did literature become an increasingly important means of social communication. ${ }^{6}$ Government-supported publishing initiatives aimed at providing affordable editions to a mass audience-notably the Editorial Quimantú-increased print runs by ten- and even twenty-fold under Allende (Herlinghaus, "Soziale Existenzbedingungen" 1428-29). Dramatic increases in Chilean literacy and circulation of national and international belles lettres were followed by radical censorship and media control in the wake of the coup (1427; 1431). The marked shift from belles lettres and a socially oriented national literature to the promotion of mass-cultural forms such as radio and film under Pinochet was an attempt to "depoliticize" arts entertainment (1432-34).

Critics thus locate a radicalized engagement with themes and structures of intermediality as part of a larger shift away from what Octavio Paz famously described as the compensatory modernism of the Boom and toward the aesthetics and conventions of popular audiovisual media in the post-Boom. It was as part of a larger cultural resurgence of mass media and state attempts to displace and depoliticize literary fiction that many authors of "the generation of ' 68 " adopted intermediality as an oppositional aesthetic leading up to and following the relaxation of censorship laws around 1983.

At its most successful, Blonder Tango's intermediality is also an instance of intertextual translation in both the book and the film versions: for example, in the process of filming scenes set in a Chilean concentration camp, Chilean exiles cast as detainees began to sing Schiller's/Beethoven's "Ode an die Freude." The tradition of singing the song when a prisoner was released to an unknown future-possibly execution, disappearance, or deportation-was unscripted and caught the East German production crew by surprise. The cultural significance of the song and its singing were not immediately legible and had to be explained before filming could continue. The film version preserves the song, which spontaneously mobilized pre-existing contextual translations from Germany to Chile and back that may otherwise never have been made. ${ }^{7} \mathrm{~A}$ marginal aesthetic of the Chilean concentration camps (the prisoners' rendition of the "Ode") is brought into productive tension with an ostensibly universal aesthetic (European symphony performance), bearing out not only Herlinghaus's criterion of transformative play among heterogeneous discursive systems, but also critic Jesús Martín Barbero's description of intermedial texts as non-contemporaneous (Herlinghaus, Intermedialität 20). The rele- 
vance of the nineteenth-century music and lyrics to present-day acts of solidarity and their representation in film emerges through the always asynchronous and asymmetrical social contexts in which a media product (i.e., a medium's use-value) is consumed (20). In this instance, the intermediality of post-Boom literary production touches-however tangentially-on East German attention to Erbe and the continuity of an antifascist humanism in German-language culture in the GDR, in which past aesthetic norms and values are selectively rearticulated for a new social and political context.

Cultural referents likewise encompass authors who figured prominently in an East German literary tradition, notably Jurek Becker and Anna Seghers. Similarities of Saavedra Santis's scenario to Becker's Jakob der Lügner (underscored already in pre-production documents by Warneke and internal reviewers), form part of a larger system of reference to East German literary engagements with the Shoah. Becker's inversion of the antisemitic trope of "the lying Jew" in the figure of Jakob, who invents news of impending Soviet liberation to engender hope among occupants of his ghetto, had already been the subject of a successful DEFA adaptation in 1975 and no doubt provided an appealing point of comparison in Warneke's gambit to make Blonder Tango. Rogelio's lies retain a positive association, in part, because of the character's functional similarity to the more sympathetic Jakob.

Stefan Hiller's reference to "die Anna [Seghers's]" Mexican exile and her story Post ins gelobte Land further enmeshes Rogelio's story in East German literary history and a history of East German international solidarity. (Seghers served as president of the Liga für Völkerfreundschaft.) Post ins gelobte Land, written sometime between 1943 and 1945, likewise pivots on the double lie of dead family correspondents. Following generations of a Jewish family that settles in Paris after fleeing a Polish pogrom, Seghers tells the story of a son who writes years' worth of letters to his émigré father in Israel prior to his own death in Paris, and a group of old men who so enjoy the dead son's letters that they maintain the father's end of the correspondence from Israel to Paris after the old man's death. In this manner, Hiller, the former Spanienkämpfer, both implies his personal familiarity with German literary exiles in Mexico City during WWII and gently challenges Rogelio's originality. Saavedra Santis in fact credits the novel's reference to Seghers's story, preserved in the screen play, to a conversation with an East German reader. Only after the reader compared his text's point of departure to Seghers's story did Saavedra Santis learn of and read it. Although the novel was nearly complete, he inserted the reference as a means of conveying to a broader readership that he was aware of the similarities (personal interview). That this and other intertextual moments were a product of Chilean-East German exchange points to a level of creative reciprocity largely unexplored in German cultural studies to date.

The story's most prominent instance of an intermedial and translative motif is a recording of the tenor Josef Schmidt, a Romanian-born Jew who had 
a hugely successful radio career in the 1930s, first in Berlin and later in Belgium and the Netherlands. Schmidt died in a Swiss refugee camp in November 1942. His most famous song, "Ein Lied geht um die Welt," (the title song for a popular biographical movie about Schmidt released in 1933) literally underscores mutually imbricated cultures of internationalism, exile, and fascism at work in the novel and the film. ${ }^{8}$ While the exiled Schmidt was unable to reach the safety of the Americas, Rogelio is taken in by the proper heirs to German humanism four decades later.

The recording takes on another dimension when one considers Rogelio's insistence that his father, an avid listener, "nur Bahnhof von dem verstand, was da gesungen wird" (Saavedra Santis 77). This signifies an initial failure of translation, or at least a translation that remains incomplete, and is interestingly enough one of the few passages of the novel that is not integrated into the screen play. Idiomatically, nur Bahnhof verstehen indicates not understanding or a reduction of language to its most rudimentary communicative functions, as with a poorly mastered touristic language of nouns and learned phrases: Wie komme ich zum Bahnhof? Literal moves by exiles and "victims of fascism" across the ocean make an analogous literal, non-idiomatic translation by Rogelio as a non-native speaker of German as plausible as it is revealing. Josef Schmidt, who traveled to Mexico, Cuba, and elsewhere at the height of his popularity, and Rogelio both make transatlantic crossings; as a commodity, the recording is packaged, transported and repeatedly exchanged. What is in effect understood of the recording and the renowned tenor is Bahnhof as a site of arrivals and departures, of relay and of movement.

If the song is a leitmotiv for solidarity, the consequences of not understanding are potentially far-reaching. The problem becomes all the more apparent when one attends to the film's more localized exchanges and performances of the Schmidt recording. Cornelia, the real object of Rogelio's desire and fictive wife and mother of his child in countless letters home, finds the recording old-fashioned kitsch. Rogelio makes her a present of the record, but, after a single night together, she returns it with a note that reads only: "es war nett." Rogelio's second attempt to share the record is markedly more successful, but also markedly less timely. He develops a relationship with an elderly neighbor, Frau Hube, who recalls attending a live performance by Schmidt before WWII and the deaths of her husband and two sons on the Eastern Front. The complex of place names and times that punctuate her story is exemplary of what Brigitte Thurm terms the "Gratwanderung zwischen Alltag und Geschichte" (92-93) articulated around the song and what contemporary reviewer Peter Ahrens foregrounded as Blonder Tango's "tiefes Empfinden für die historische Dimension zeitgenössischer Biographien" (93). After the woman's death, Rogelio retrieves the record from her apartment. Ultimately, the record again meets with an ambivalent East German response in the film's final, surreal sequence, in which Rogelio's Chilean dream world encroaches visibly on the 
space of his East German reality. Rogelio takes the stage at the theater's carnival masquerade, only to be interrupted by his bewildered public of theater workers. He then deliberately breaks the record at the moment he publicly performs or mimes its content.

Third and finally, I turn to the translation of German and Chilean history and memory with recourse to specifically literary/filmic forms in Blonder Tango. The film's use of non-diegetic historical material-most notably Allende's final, emotional speech and tribute to the historical project of Chilean socialism - and Warneke's collaboration with documentary cameraman Thomas Plenert can be seen as extensions of Warneke's experiments with what he termed "documentary feature film." Most fully articulated in his master's thesis, Warneke developed his concept in critical relation to both UFA studio films and Soviet documentaries that were widely screened in the Soviet Zone, and, later, East Germany prior to the development of a new national cinema ("Der dokumentare Spielfilm"). Developments in Italian neorealism, closely followed by film students in the GDR, corresponded to and reinforced Warneke's interest in making films about the realities of socialism rather than projecting its desired outcomes in studio films made according to the old UFA mold. Increasingly attentive to the "Primat der Wirklichkeit," Warneke sought to maximize authentic and documentary elements of feature film-making (Die Schönheit 63). Technological developments in film freed directors and cameramen from the confines of the studio, and it is no coincidence that Warneke went to great lengths to secure a partnership with Plenert in spite of strict institutional divisions among studio feature and documentary production teams. ${ }^{9}$ Simultaneously introducing and withholding a generic distinction and the respective truth claims its constituent terms imply, the treatment of Blonder Tango as documentary feature film prompts me to query the significance of producing a multiple, fictional account of events in German, East German, and Chilean history. By extension, I query the affinities and differences in German and Latin American practices of constituting, shaping, and promulgating truths through media which are also art.

Documentary impulses in German film and literature, ranging from reportage to documentary drama, Soviet montage, and the reception of Italian neorealism, exemplify aesthetic engagements with material realities which informed Warneke's approach to feature filmmaking. Saavedra Santis's work, too, stands in complex relation to long-salient paraliterary forms in Latin America, including journalism and the testimonial novel. The testimonial dimension of Chilean writing is characterized by author and critic Ariel Dorfman as simultaneously accountable to a collective memory of violence and to a concept of the real fundamentally open to contradiction in and through literature. It pivots-like Warneke's documentary feature film-on the blurred boundaries of the notions of documentary and literariness (Dorfman 170-234). 
At least as interesting as the novel's and film's respective investments in social communication and authenticity are the many instances in the screenplay where documentary was conceived, but then withheld. Extensive use of documentary footage from the Spanish Civil War, Pinochet's concentration camps, and Nazi Germany was intended to appear in at least three separate film sequences, and Warneke considered it to be essential to the effective translation of the German antifascist Hiller from novel to film and to any claims the film might have on authenticity:

Die Notwendigkeit einer derartigen Ebene erscheint mir allerdings außer Zweifel. Im Roman von Omar Saavedra Santis ist es der alte Emigrant Stephan Hiller, der mit seinen Reflexionen und Reden dem Stoff eine enorme politische Höhe verleiht. Diese Höhe beizubehalten im Film, ohne daß sich der verbale Anteil ins Unfilmische steigert, wäre die Aufgabe einer solchen Kompilationsebene. ("Treatment" IV-V) ${ }^{10}$

Warneke devotes nearly a page of his five-page treatment to a description of the compilation level, which he envisioned producing by subjecting original documentary images to a thorough re-working under an animation camera in order to achieve his desired effects of estrangement, acceleration, and subjective association. "Oxberry!" appears in his text as an exclamation rather than a medium ("Treatment" IV). (By the 1970s the name of inventor and manufacturer John Oxberry was synonymous with the standard animation camera, a stop-motion stand machine with a camera positioned perpendicular to a movable tabletop.)

Warneke's direction repeatedly underscores parallelism and even the imperceptible mixing and transition among images from disparate contexts and sources ("Treatment" IV). Anchored in the reality of documentary sources, the fiction of two antifascist exiles' deep historical and emotional identification was, it seems, to project and articulate an alternate reality and renewed political commitment on the part of both Rogelio and Hiller for a GDR audience. Suspended between associative and narrative modes, these scenes were, above all else, to be characterized by their authenticity (IV-V).

But, as Saavedra Santis remarked in explaining his disappointment with many identity-based casting decisions, "Authentizität ist nicht Echtheit" (personal interview). Casting real antifascists who had returned to the GDR after Mexican exile, for example, ultimately did not serve the complex system of translations that both the novel and the screenplay set up. An unevenness of emotional and political experiences surrounding the film as a project of comparison and translation, apparent in diverse accounts of the film and its production, suggests that Saavedra Santis's comment may reveal a much larger problematic in relating expressions of linguistic, cultural, and political positions. To what extent do authentic expressions of solidarity rely on and/or 
contribute to incomplete or unresolved representations of cultural and political truth, potentially undermining the act of solidarity?

Indebted to comparatist approaches to historiography in many respects, the distinction between narratives of juxtaposition and narratives of connection or resolution productively sums up the inter-and transmedial aspects of Blonder Tango (the film); translative dimensions of language, history, and memory; and documentary impulses in various fictional and paraliterary genres. ${ }^{11}$ Juxtaposing two modes of thinking about the place of German and Chilean (anti)fascisms in personal stories and in histories, Rogelio advances the idea that "Geschichten sind rund, wie ein Ball"; in the novel, he is ultimately contradicted by Hiller, whose comment serves to resume rather than to resolve a larger narrative structure and to suggest a necessarily tandem dialectic in which all stories have a stake without sharing an identity per se. ${ }^{12}$ In the film, by contrast, the visual narrative is rounded by a return to images of an icy sea-possibly the Baltic, possibly the Pacific-and Hiller never speaks his line. It is here that we see a key difference in the historical and translative worldviews at work in the film and the novel: the difference between the novel as an instance of juxtaposition and the film as one of resolution resides in the particular possibilities each leaves open-or forecloses-for the emergence of productive differences rather than defeated or defeating similarities to other (anti)fascisms.

\section{Always the Same Film?}

Enjoying Hiller's German potato salad in the novel, Rogelio interrupts his own musings on exile, loneliness, and materiality to wonder aloud: " $\mathrm{Ha}$, ich weiß nicht, warum ich Ihnen von Dingen erzähle, die Sie und andere in Mexiko erlebt haben: Es ist letztendlich der gleiche Film" (Saavedra Santis 56). Is the reader/viewer to agree? Perhaps. If exile is exile like a tango is a tangothat is, a structure of movement and of feeling which, although clearly identifiable, nonetheless requires improvisation, and the most common lyrical conceit of which is loneliness and loves betrayed - then the structures and even emotions of exile may share a kind of minimal generic equivalence. But, like all metaphors, it is the limits of tango, exile, and film which permit the literal or material to take literary form in Warneke's film and Saavedra Santis's novel. The film is the same (der Gleiche), but not the self-same (der Selbe). In translative modes of juxtaposition and resolution alike, cultural cliché-here in the contradictory play of "blonder Tango"-is the enabling and destabilizing conceit of Warneke's transmedial translation, recognizable because substantively alike, but not identical or even strictly equivalent.

Initially coined to describe a mode of copying, of literally stereotyping, cliché has perhaps always been a mode of translation. Compounding its connotative possibilities, the tango is itself famously translated, gaining re- 
spectability and cultural cachet only after moving from the brothels of Buenos Aires and Montevideo to Paris and back again, recuperable by elite classes because Europeanized and thus newly fashionable. The melancholy of tango and exile, each figure holding fast to its lost object(s), makes for an unusual expression of socialist solidarity in the recurring pair "Solidarität und Zärtlichkeit." Here again, differences in the articulation of the twinned concepts in the novel and the screenplay/translation are instructive.

As already noted, the prominence of the tango figure in Saavedra Santis's novel emerges only at the moment of translation, but less developed references to dance in the novel are also symptomatic of a complicated relationship between translation and cultural cliché. The novel's only sustained reference to tango can be found in a detailed account of how best to seduce East German women. The passage illustrates Saavedra Santis's delightful humor and sense for the personal uses and abuses of the political, too often overlooked in socialist realism's pursuit of a positive socialist hero. Recounting advice given him by another Chilean exile and friend, Rogelio cautions against the overt display of difference in favor of an incremental approach, a carefully orchestrated series of transitions from the familiar to a familiar exotic which, rather than emphasize a real difference, foregrounds an attractive cliché of difference:

Niemals mit Folklore anfangen: Tangos oder Boleros oder gar peruanische Walzer sind in diesen nördlichen Breitengraden am Anfang der Eroberung von blonden Venushügeln harmlose Impfstoffe, sie bewirken genau das Gegenteil, verursachen Schläfrigkeit, Apathie und das Risiko eines Fußtritts in den Hintern, weil sie langweilen. Man muß mit einem geometrischen Ausgangspunkt anfangen, einer Platte von Manfred Krug zum Beispiel; da hat man parallel dazu die Möglichkeit, auf das Problem der beiden deutschen Staaten einzugehen und zu dokumentieren, daß man genau weiß, wo man sich befindet, aber bitte ohne Übertreibung, es handelt sich schließlich nicht um ein politisches Forum. Auch sollte man die Platte nicht bis zum Ende hören, zwei Titel genügen. Danach muß unverzüglich zu den Klassikern übergegangen werden [...]. Von den soeben genannten bevorzuge man Simon \& Garfunkel, und mit "El Cóndor pasa" kann man auf elegante Weise zum Süden des Río Grande springen, zu den Intis zum Beispiel, aber nicht übertreiben, höchstens drei Lieder. [A suggested playlist follows-JHT] Erst dann ist es angebracht, zu den Tangos, Boleros, Walzern oder Cumbias überzugehen. (69-70)

Here and throughout the text, Rogelio participates in an economy of clichés of the German and the Chilean alike. In addition to the absence of any straightforwardly sympathetic protagonist, there is also no straightforwardly sympathetic or preferred mode of reading cliché or broaching the presumed relationship of political and cultural authenticity in multiple socialist contexts. The effect of the tango cliché thus deployed underscores artifice and reveals both politics and culture to be profoundly performative and subject to cynical manipulation. 
Warneke's film version choreographs clichés with markedly less irony. Screen directions for the penultimate scene indicate: "Rogelio führt Cornelia zum Tanz und versucht der ziemlich deutschen Musik einen südamerikanischen Tanz aufzuzwingen. Die Absicht ist dabei, Chilenisches sichtbar werden zu lassen in typischen DDR-Formen und umgekehrt" ("Lektoratsdrehbuch" 141). Rogelio and Cornelia, the blonde, blue-eyed object of his infatuation and desire, never dance the tango at all. Instead, their awkward dance ends with each dissolving back into the crowd. The screen direction nonetheless encapsulates Warneke's sense of the project as a careful choreography of different cultural footfalls: "Ich hatte den Eindruck, daß bei den Südamerikanern, in dem Fall den Chilenen, eigentlich mehr gehupft wird, während bei uns schwerfällig stapfend vorgegangen wird, daß ein ganz anderer stilistischer Umgang mit den Dingen vorhanden war" (Warneke, Die Schönheit 159-60).

Considering the novel and the film together brings authorship and translation into a similar tension. As improvisations around an unpublished Spanish text, they, too, are involved in a kind of tango. Partner dance, with its variations and improvised steps, relies on embodied conventions. Its success or failure resides not in the individual, but in the ability of partners to communicate nonverbally, anticipate one another's movements, and manipulate steps in tandem; choreography, in that sense, provides a framework for movement, but it relies on the dancers to invest that movement with meaning. Different translative processes, including the reworking of cultural and political history, intermediality, and the physical, idiomatic, and literal translation of language, at times work at cross-purposes in the novel and the film, but solidarity and exile provide a framework in each.

The premium placed on authentic revolutionary subjectivity in socialist political discourse is paralleled by that placed on authentic translation in the study of literature and linguistics. Blonder Tango prompts us to reconsider both. What, to resume Saavedra Santis's distinction, is the proper relationship of Authentizität and Echtheit? To what or to whom should a solidary translation be "faithful"? If we take Doris Sommer at her word, there is not necessarily reason to parse or prioritize the authentic and the real: "Authenticity means being more than one" (xxii). Naoki Sakai puts it somewhat differently, but with consequences not dissimilar for reading Blonder Tango as a choreography of exile on a floor of antifascist memories: "the translator is someone who cannot say 'I'" (74). This would seem to leave "we" as the only possible firstperson speaking position. Is the plural voice of translation always primed for solidarity, for a disposition of unity in multiplicity, however imperfect? These are questions whose complex theoretical and political relation has itself yet to be choreographed, but which improvise, however imperfectly they may be coupled, in the East German-Chilean discourse on exile, antifascism, and solidarity of which Warneke's Blonder Tango is a part. Dissonant, off-beat, even 
stepping on one another's toes-perhaps solidarity is best described as an openness to being tripped up, a willingness to translate with a limp rather than not at all because, as Hiller reminds Rogelio: "Undankbarkeit ist das Risiko der Solidarität."

\section{Notes}

${ }^{1}$ I gratefully acknowledge Andrew Oppenheimer for his extensive comments. Hiltrud Schulz at the DEFA Library at the University of Massachusetts at Amherst was helpful in identifying potential sources and contacts in the early stages of my research. Erika Richter, Omar Saavedra Santis, and Thomas Plenert generously agreed to discuss their memories of work on the film.

${ }^{2}$ For an overview of the material and rhetorical contexts for thinking about Latin America in post-Wall East and West Germany, see Trnka (especially 13-24).

${ }^{3}$ East German reviews and accounts of local film premieres describe Solidaritätsveranstaltungen, often planned and executed in conjunction with Chilean exile organizations. "Einsatzhinweise" promoting solidarity activities were suggested by the distributors. See "Progress Einsatzkarte."

${ }^{4}$ Personal interview with Dramaturge Erika Richter; see also "Stellungsnahme" and "Einschätzung." Saavedra Santis attributes problems in the scene to casting real-life antifascist and Mexican exile Gerhard Meyer in the role of Hiller; Richter maintains that these less successful scenes with Hiller could be traced to a "plakativ" and journalistic impulse in the novel, a weakness in the source text rather than of the film's conception as such. In a series of published interviews, Warneke tempers his enthusiasm only with respect to the Hiller scenes: He agrees that they could have been significantly reduced - not because of didacticism per se but because their dialogueheavy character was inappropriate to film (Die Schönheit 168).

${ }^{5}$ Notable examples include: Konrad Weiss, Wenn du an Chile denkst, 1977; Horst Winter, Gladys Marin —Chile, 1974; and Joachim Hadaschick, Venceremos Solidaridad -Wie werden siegen durch die Solidarität, 1977.

${ }^{6}$ For a summary of twentieth-century developments in Chilean literacy, bookconsumption, and publishing, see Herlinghaus, "Soziale Existenzbedingungen" 1427.

${ }^{7}$ See for example Holland-Moritz.

${ }^{8}$ For more on Schmidt, see Fassbind and Pfister.

${ }^{9}$ See Warneke, Die Schönheit (141-42); Richter; Plenert.

${ }^{10}$ Why this Kompilationsebene was ultimately not included is unclear. Warneke's film treatment makes an argument for its necessity even while acknowledging that the process would require labor disproportional to its anticipated screen time. Production documents reflect budget and technical requests for animation, as well as an at least partial list of archival footage requested. See "Direktionsvorlage."

${ }^{11}$ While she does not use the terms I have coined here, the thrust of this argument is developed in Sandra Bermann's compelling reading of translating lived experience into history in the work of René Char ("Translating History" especially 263-65).

${ }^{12}$ In the novel, Hiller explains the relation as follows: "Such nicht nach einem zu großen Vergleich zwischen deinen traurigen Geschichten und den meinen, die auch traurig sind; übertreibe nicht diesen Vergleich, denn die Geschichten sind nicht rund, 
wie du glaubst, sondern entwickeln sich spiralförmig nach oben, von wo aus, wenn wir nicht ein für allemal dazugelernt haben, der Fall absolut vertikal sein wird; wenn ich so mit dir rede, Junge, dann, weil ich nichts besseres tun kann, als von mir selber zu sprechen" (Saavedra Santis 85).

\section{Works Cited}

Ahrens, Peter. “'Blonder Tango'-der weitere Blick." Die Weltbühne 18/1986 (6 May 1986). Reproduced in: "Ausgewählte Film- und Fernsehrezenzionen 1. Januar 1986-31. Juli 1987." Podium und Werkstatt 30/31: 41-45.

Bermann, Sandra, and Michael Wood. "Introduction." Nation, Language, and the Ethics of Translation. Princeton: Princeton UP, 2005: 1-10.

Bermann, Sandra. "Translating History." Nation, Language, and the Ethics of Translation. Ed. Sandra Bermann and Michael Wood. Princeton: Princeton UP, 2005: 257-73.

Byg, Barton. "Solidarity and Exile: Blonder Tango and the East German Fantasy of the Third World." Moving Pictures, Migrating Identities. Ed. Eva Rueschmann. Jackson: UP of Mississippi, 2003: 55-71.

Dorfman, Ariel. "Código politico y código literario: el género testimonio en Chile de hoy." Testimonio y literatura. Ed. René Jara and Hernán Vidal. Minneapolis: Institute for the Study of Ideology and Literatures, 1985: 170-234.

"Direktionsvorlage v.d. 3.1.1985: Betr: Antrag zur Aufnahme in den Produktionsplan 1985 des Projekts." BArch DR1/ 11606. Ministerium für Kultur. HV Film. Filmanalysen 1979-1987, Berlin.

Ein Lied geht um die Welt. Dir. Richard Oswald. 1933. Film.

"Einschätzung des Szenariums 'Blonder Tango' (1. Fassung)." Abteilung Künstlerischer Produktion. Bibliothek des Filmarchivs des Bundesarchivs, Berlin, 1985.

"Ergebnisanalyse der Auswertungsgespräche des Jahres 1980" 27.01.81. BArch DR1/ 11606. Ministerium für Kultur. HV Film. Filmanalysen 1979-1987.

Fassbind, Alfred A., and Werner Pfister.Joseph Schmidt: Ein Lied geht um die Welt. Spuren einer Legende. Eine Biographie. Zurich: Schweizer Verlagshaus, 1992.

Herlinghaus, Hermann. Intermedialität als Erzählerfahrung: Isabel Allende, José Donoso, und Antonio Skármeta im Dialog mit Film, Fernsehen, Theater. Frankfurt: Peter Lang, 1994.

—. "Soziale Existenzbedingungen der chilenischen Literatur unter dem Faschismus. Überlegungen zu '15 Jahre chilenische Literatur im antifaschistischen Widerstand." Weimarer Beiträge 34.9 (1988): 1425-1445.

Holland-Moritz, Renate. "Blonder Tango." Eulenspiegel. Kino-Eule. 9 May 1986.

"Lektoratsdrehbuch 'Blonder Tango." VEB DEFA Studio für Spielfilme Gruppe "Babelsberg." Filmarchiv Potsdam DB 86, 1985.

Plenert, Thomas. Personal interview. 29 July 2008.

Polster, Martina. Chilenische Exilliteratur in der DDR. Marburg: Tectum, 2001.

"Progress Einsatzkarte." FArch/BArch 31 881, Berlin.

Richter, Erika. Personal interviews. 11 July and 29 July 2008.

Saavedra Santis, Omar. Blonder Tango. Berlin: Verlag Neues Lebens, 1983. . Personal interview. 17 July, 2008.

Said, Edward. Culture and Imperialism. New York: Vintage Books, 1994. 
Sakai, Naoki. "Translation." Theory, Culture and Society 23 (2006): 71-86.

Schwarz, Jürgen. "Das geträumte und das reale Leben eines Zeitgenossen." Freie Presse 24 Apr. 1986.

Sommer, Doris. Bilingual Aesthetics: ANew Sentimental Education. Durham: Duke UP, 2004.

“Stellungsnahme zum Rohschnitt 'Blonder Tango' am 4.9.85.” Abteilung Künstlerischer Produktion. Bibliothek des Filmarchivs des Bundesarchivs, Berlin.

Thurm, Brigitte. "Analyse und Betrachtung DDR-Spielfilme in den 80er Jahren." Beiträge zur Film- und Fernsehwissenschaft 30/36 (1989): 86-93.

"Rezensionen." FArch/BArch 31 881, Berlin.

Trnka, Jamie H.. Revolutionary Subjects: Literature and Geoculture in East and West German Writings about Latin America, 1961-present. Diss. Cornell University, 2007.

Voss, Margit. Presseheft: "Gespräch mit Regisseur Lothar Warneke," Filme des Monats: 8-10. FArch/BArch 31 881, Berlin.

Warneke, Lothar. "Der dokumentare Spielfilm." Wissenschaftliche Mitteilungen. Sonderheft anläßlich des 10jährigen Bestehens der Deutschen Hochschule für Filmkunst, October 1964.

Die Schönheit dieser Welt. Berlin: DEFA Stiftung, 2005.

"Treatment." Filmmuseum Potsdam. Nachlaß Warneke. 